\title{
Separable programming for aggregate production planning - A high-order cost case
}

\author{
J.T. Meij \\ Department of Mechanical Engineering, University of Stellenbosch
}

\begin{abstract}
Many production managers are faced with the problem of planning production, inventory and work-force under the constraint of limited resources to meet a seasonal demand. Considerable research has been done on this planning problem and various planning models have been introduced. In those cases where linearity of the cost functions of an undertaking may reasonably be assumed, an ordinary linear program. ming model suffices. In many cases, however, this simple linear approach to certain essentially non-linear cost functions is unacceptable owing to the gross approximation made.

Separable programming (SEP) is introduced as a solution methodology to this aggregate production planning problem in a com plex, high-order cost structure case. The cost structure was used by Goodman for the application of goal programming (GP) in this field. The Goodman GP model makes provision for positive or negative slack for the production level, work-force level and inventory level with penalty costs for these slack-deviations. Goodman also made use of a 'sectioning search' model for this high-order cost case to serve as a measure for his GP model. A comparison is made between the results of these three approaches. SEP offered an improvement of more than $4 \%$ in total cost in comparison with the sectioning search model, and performs $26 \%$ better than the GP model.

S. Afr. J. Bus. Mgmt. 1982, 13: 18- 22
\end{abstract}

Baie produksiebestuurders word gekonfronteer met die probleem van die beplanning van produksiehoeveelheid, voorraadvlak en arbeidsmag met inagneming van die beperkte bronne tot die onderneming se beskikking vir die bevrediging van 'n seisoenale aanvraag. Heelwat navorsing is al oor hierdie beplanningsprobleem gedoen en ' $n$ ver. skeidenheid wiskundige en ander modelle is getoets. In die gevalle waar lineère kostefunksies by 'n onderneming met 'n groot mate van sekerheid aanvaar kan word, kan van gewone lineère programmeringsmodelle gebruik gemaak word. In baie ander gevalle is die aan. name van ' $n$ lineère kostestruktuur egter onaanvaarbaar weens growwe aannames wat gemaak word.

Skeibare programmering (SEP) word voorgestel as 'n oplossingsmetodiek vir die taktiese produksiebeplanningsprobleem in ' $n$ komplekse, hoe-orde, kostestruktuurgeval. Hierdie kostestruktuur is deur Goodman gebruik vir die toepassing van doelwit-programmering (GP) in dié gebied. Die Goodman doelwit-programmeringsmodel maak voorsiening vir positiewe en negatiewe afwykings vir die produksievlak, arbeidsmagvlak en voorraadvlak met boete-koste vir die afwykings. Goodman gebruik ook 'n 'verdeling-soek'-model, vir hierdie hoë-orde koste-geval, vir vergelykingsdoeleindes teen sy GP-model. 'n Vergelyking word gemaak tussen die resultate van hierdie drie benaderings. Die SEP-model toon 'n verbetering van $4 \%$ op die totale koste van die verdeling-soek-model en presteer $26 \%$ beter as die GP-model.

S.-Afr. Tydskr. Bedry/sl. 1982, 13: 18-22

\section{J.T. Melj}

Professor, Department of Mechanical Engineering, University of Stellenbosch,

Stellenbosch 7600, Republic of South Africa
The aggregate production planning problem, in its simplest form, may be stated as follows:

To develop the lowest cost production plan given a fluctuating demand pattern and limited production resources. Various solution methodologies to solve this optimization problem have been suggested. Holt, Modigliani, Muth and Simon ${ }^{1.2}$ developed the Linear Decision Rule (LDR) approach for assumed quadratic cost structures. Their published application of LDR at a paint factory served as a yardstick for many different models. Hanssman and Hess ${ }^{3}$ used the LDR model as a basis for the development of their programming model because . . . 'it appears, however, that in the majority of practical applications and theoretical models the cost functions are assumed to be linear'.

Based on this approach Goodman ${ }^{4,5}$ presented an alternative linearization method and used goal programming (GP) to solve the paint factory problem. In comparison with linear programming (LP) and LDR, goal programming gave good results for the quadratic cost function case. However, in the case of the higher-order cost function used by Goodman, the GP approach failed in comparison with a computer search method (sectioning search).

In this paper the use of separable programming (SEP) for the case of high-order cost functions is shown to give excellent results. The advantage of this method lies in the fact that ordinary linear programming algorithms can be used to solve the model. To develop his fourth-order cost function Goodman made use of a hypothetical real world set of data, reproduced in Table 1. SEP is also applied to this set of data to test its ability to fit the real world situation.

\section{Goal programming model}

The Goodman GP model was developed to fit the hypothetical historical cost data-set shown in Table 1. In this table only the absolute values of changes are shown. It is assumed that the costs are symmetrical about the zero cost point of each variable.

The cost model is constructed as follows. Define:

$P_{t}=$ Production rate in period $t$

$D_{t}=$ Demand in period $t$

$I_{t}=$ Inventory level at the end of period $t$

$W_{t}=$ Work-force level in period $t$

By fitting curvilinear segments to a set of the hypothe- 
tical cost data the following cost functions were obtained:

$340 W_{1}$ Regular payroll.

$0,2\left(P_{t}^{\prime}-6 W_{t}\right)^{4} \quad$ Overtime and idletime

$64\left(W_{t}-W_{t-1}\right)^{4} \quad$ Hiring and layoff.

$0,1\left(P_{t}-P_{t-1}\right)^{4} \quad$ Production level increase and decrease.

$0,1(I,-320)^{4} \quad$ Inventory and shortages.

These cost functions lead to the following total cost model. Minimize the total cost:

$$
\begin{aligned}
\sum_{t=1}^{n} & {\left[340 W_{t}+0,2\left(P_{t}-6 W_{t}\right)^{4}\right.} \\
& +64\left(W_{t}-W_{t-1}\right)^{4}+0,1\left(P_{t}-P_{t-1}\right)^{4} \\
& \left.+0,1\left(I_{t}-320\right)^{4}\right]
\end{aligned}
$$

Subject to:

$$
\begin{aligned}
& I_{t}=I_{t-1}+P_{t}-D_{t} \\
& P_{t} \geqslant 0 \\
& W_{t} \geqslant 0 \\
& \text { for } t=1,2,3 \ldots n
\end{aligned}
$$

Goodman solved this model with goal programming. It is based upon the notion that each of the fourth-order cost terms becomes zero when the expression inside the parentheses is zero. Minimization of each cost term is regarded as a goal and is formulated as a constraint. It is necessary to allow positive and negative slack in these constraints because it is not possible to minimize simultaneously all the cost terms while at the same time satisfying the demand requirements. The resulting goal constraints can be expressed as:

$$
\begin{aligned}
P_{t}-6 W_{t}+Q_{t}^{+}-Q_{t}^{-} & =0 \\
W_{t}-W_{t-1}+R_{t}^{+}-R_{t}^{-} & =0 \\
P_{t}-P_{t-1}+S_{t}^{+}-S_{t}^{-} & =0 \\
I_{t}-320+T_{t}^{+}-T_{t}^{-} & =0 \\
I_{t-1}+P_{t}-D_{t} & =I_{t} \\
P_{t} & \geqslant 0 \\
W_{t} & \geqslant 0 \\
t & =1,2 \ldots n,
\end{aligned}
$$

where $Q, R, S$ and $T$ are slack variables.

Positive coefficients are assigned to the slack variables in the objective function. The effect is to penalize deviations from the desired goals. The objective function is given by:

$$
\begin{aligned}
\operatorname{Min} \sum_{t=1}^{n} & {\left[340 W_{t}+C_{1} Q_{t}^{+}+C_{1} Q_{t}^{-}+C_{2} R_{t}^{+}\right.} \\
& \left.+C_{2} R_{t}^{-}+C_{3} S_{t}^{+}+C_{3} S_{t}^{-}+C_{4} T_{t}^{+}+C_{4} T_{t}^{-}\right]
\end{aligned}
$$

The coefficients $C_{1}, C_{2}, C_{3}$ and $C_{4}$ must be selected to give good cost approximations of the cost terms that they represent. This is done by approximating the cost functions by linear segments. The slopes of these linear segments give the desired cost coefficients. (See Figure 1.) The slopes are set so that area $\mathbf{A}$ is equivalent to area B, for example:

$$
C_{2}=\frac{y}{\max \left|W_{1}-W_{1,1}\right|} .
$$

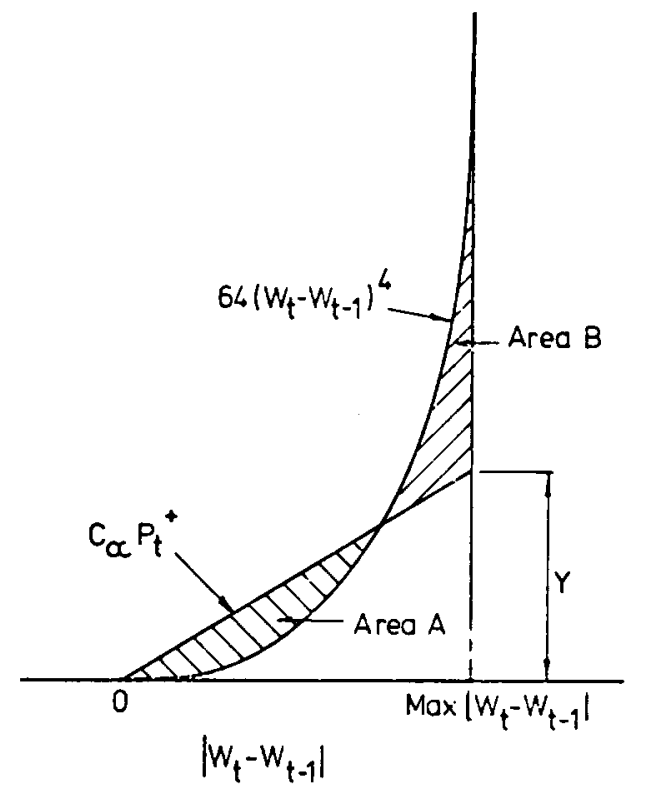

Figure 1 Approximation of a cost function by a linear segment (Goodman).

\section{Separable programming formulation}

In separable programming the same principle is applied as in goal programming. The main difference is that the cost terms are now approximated by several linear segments. (See Figure 2.)

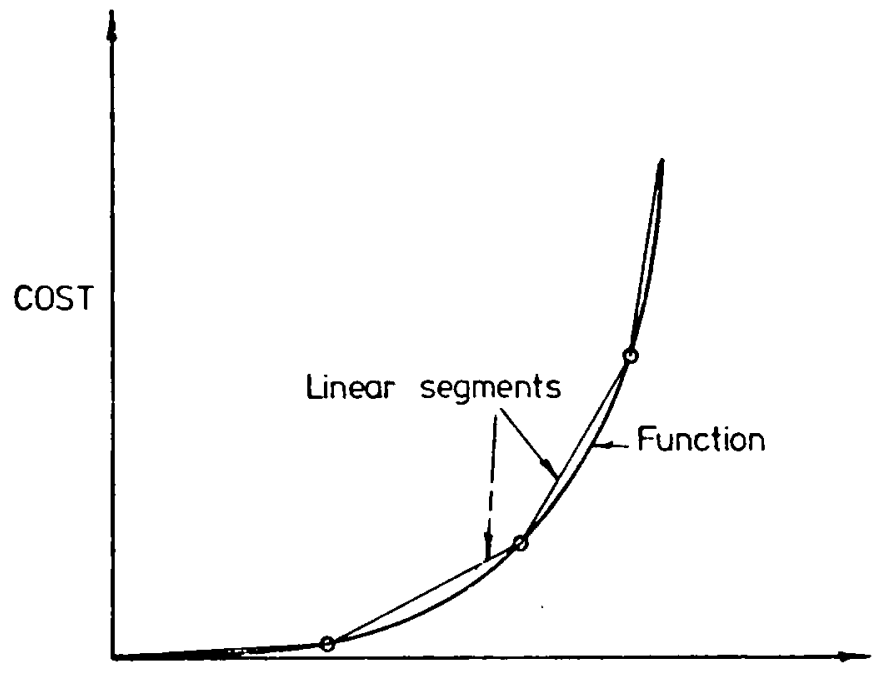

COST VARIABLE

Figure 2 Approximation of high-order cost function by several linear segments. 
The following model can thus be formulated. Define:

$O T=$ Overtime

$O A=$ Idle time

$H T=$ Increase in work-force (Number of people)

$H A=$ Decrease in work-force (Number of people)

$P T=$ Increase in production rate

$P A=$ Decrease in production rate

$V T=$ Inventory

$V A=$ Shortages

$W=$ Normal work-force

$P=$ Production rate

$I=$ Net inventory level

$D=$ Demand

$t=$ Time period

$T=$ Number of time periods (Planning horizon)

$b, c, d, e, f, g, u, s=$ Constants from piecewise approximations for variables

$B, C, D, E, F, G, U, S=$ Cost constants from piecewise approximation

$i, j, k, l, m, n, q, r=$ Inter-subscripts determining the sequence of the piecewise segments.

$\boldsymbol{G}=$ Number of piecewise segments required (kept constant to simplify the formulation)

$a=$ Regular work-force cost coefficient

$Z=$ Ratio of production to work-force (productivity constant).

The separable programming model can be expressed as: Minimize the objective function:

$$
\begin{aligned}
\sum_{i=1}^{I} & {\left[a W_{t}+\sum_{i=1}^{G} B_{i} O T_{i t}+\sum_{j=1}^{G} C_{j} O A_{j t}\right.} \\
& +\sum_{k=1}^{g} D_{k} H T_{k T}+\sum_{i=1}^{g} E_{l} H A_{t t}+\sum_{m-1}^{G} F_{m} P T_{m t} \\
& \left.+\sum_{n=1}^{g} G_{n} P A_{n t}+\sum_{q=1}^{g} U_{q} V T_{q t}+\sum_{r=1}^{G} S_{r} V A_{r t}\right]
\end{aligned}
$$

Subject to the constraints:

$$
\begin{aligned}
& W_{1}-W_{1-1}-H T_{t}+H A_{t}=0 \\
& P_{1}-P_{1-1}-P T_{1}+P T_{t}=0 \\
& I_{1}-320-V T_{1}+V A_{1}=0 \\
& P_{1}-6 W_{t}-O T_{1}+O A_{1}=0
\end{aligned}
$$

$$
\begin{gathered}
P_{t}-I_{t}+I_{t-1}=D_{t} \\
W_{t} \geqslant 0 \\
P_{t} \geqslant 0 \\
\sum_{t=1}^{G} b_{i} O T_{t}-O T_{t}+Z W_{t}=0 \\
\sum_{j=1}^{G} e_{j} O A_{j t}-O A_{t}+Z W_{t}=0 \\
\sum_{k=1}^{G} d_{k} H T_{k t}-H T_{t}=0 \\
\sum_{i=1}^{G} e_{t} H A_{t l}-H A_{t}=0 \\
\sum_{m=1}^{G} f_{m} P T_{m t}-P T_{t}=0 \\
\sum_{n=1}^{G} g_{n} P A_{n t}-P A_{t}=0 \\
\sum_{q=1}^{G} u_{q} V T_{q t}-V T_{t}+320=0 \\
\sum_{t=1}^{G} s_{r} V A_{r t}-V A_{t}+320=0
\end{gathered}
$$

for all $t=1,2 \ldots$. Note: $G$ may vary for each variable depending on the desired quality of the fit of the linear segments to the cost structure.

\section{Application of the separable programming model}

The separable programming model was applied to two alternative cost structures:

- The first run was done using costs as given by the fourth-order cost functions developed by Goodman. Each cost function was approximated by six piecewise linear segments. Thus $G=6$ in the formulation. This run will be called SEP (model application).

- The second run was done by using directly the hypothetical historical cost data shown in Table 1. Six piecewise linear segments were used to approximate each variable. This run will be called SEP (direct application).

The cost terms of both cost structures were graphed to determine the function values of the linear segments and the associated cost coefficients. It must be emphasized that the model developed when fitting the linear segments to the real world cost structure given in Table 1 must be

Table 1 Hypothetical-historical cost data by Goodman'

\begin{tabular}{cccrcrrr}
\hline$\left|W_{t}-W_{t-1}\right|$ & Cost & $\left|P_{t}-P_{t-1}\right|$ & \multicolumn{1}{c}{ Cost } & $\left|I_{t}-I\right|$ & \multicolumn{1}{c}{ Cost } & $\left|P_{t}-Z W_{t}\right|$ & \multicolumn{1}{c}{ Cost } \\
\hline 0 & 0 & 1 & 1 & 1 & 1 & 0 & 0 \\
1 & 66 & 2 & 2 & 2 & 2 & 1 & 1 \\
2 & 1001 & 4 & 24 & 3 & 9 & 2 & 4 \\
3 & 5210 & 5 & 68 & 4 & 28 & 3 & 14 \\
4 & 20100 & 7 & 225 & 6 & 122 & 5 & 131 \\
5 & 38120 & 10 & 1049 & 8 & 392 & 7 & 457 \\
7 & 86300 & 16 & 6310 & 11 & 1370 & 10 & 1876 \\
9 & 139200 & 22 & 26100 & 15 & 5417 & 12 & 3780 \\
12 & 224400 & 34 & 123400 & 21 & 18240 & 14 & 7795 \\
14 & 279600 & 52 & 487200 & 39 & 231200 & 18 & 20600 \\
19 & 401100 & 87 & 1140000 & 51 & 474400 & 22 & 34900 \\
25 & 698700 & 150 & 2224000 & 70 & 702500 & 30 & 58200 \\
\hline
\end{tabular}


Table 2 Aggregate production plan using separable programming applied to the high-order cost model and applied to the real-world cost structure

\begin{tabular}{|c|c|c|c|c|c|c|c|}
\hline \multirow[b]{2}{*}{ Period } & \multirow[b]{2}{*}{ Demand } & \multicolumn{2}{|c|}{ Production (Units) } & \multicolumn{2}{|c|}{ Work-force (Men) } & \multicolumn{2}{|c|}{ Inventory (Units) } \\
\hline & & Model application & Direct application & Model application & Direct application & Model application & Direct application \\
\hline 0 & & 450 & 450 & 75 & 75 & 320 & 320 \\
\hline 1 & 430 & 446 & 441 & 73 & 73 & 336 & 331 \\
\hline 2 & 447 & 431 & 424 & 71 & 70 & 319 & 308 \\
\hline 3 & 440 & 409 & 402 & 67 & 67 & 289 & 271 \\
\hline 4 & 316 & 378 & 380 & 64 & 65 & 350 & 335 \\
\hline 5 & 397 & 361 & 375 & 62 & 63 & 314 & 313 \\
\hline 6 & 375 & 349 & 368 & 60 & 62 & 289 & 305 \\
\hline 7 & 292 & 364 & 368 & 62 & 62 & 360 & 381 \\
\hline 8 & 458 & 395 & 390 & 64 & 64 & 297 & 312 \\
\hline 9 & 400 & 383 & 383 & 63 & 63 & 280 & 295 \\
\hline 10 & 350 & 352 & 361 & 60 & 61 & 282 & 305 \\
\hline 11 & 284 & 361 & 353 & 64 & 61 & 359 & 374 \\
\hline 12 & 400 & 401 & 375 & 69 & 64 & 360 & 348 \\
\hline 13 & 483 & 441 & 464 & 74 & 75 & 318 & 329 \\
\hline 14 & 509 & 478 & 486 & 79 & 79 & 288 & 305 \\
\hline 15 & 500 & 493 & 500 & 84 & 82 & 280 & 305 \\
\hline 16 & 475 & 508 & 492 & 89 & 84 & 313 & 322 \\
\hline 17 & 500 & 548 & 513 & 94 & 88 & 360 & 335 \\
\hline 18 & 600 & 600 & 629 & 99 & 104 & 360 & 364 \\
\hline 19 & 700 & 668 & 663 & 108 & 109 & 328 & 327 \\
\hline 20 & 700 & 708 & 685 & 113 & 112 & 337 & 312 \\
\hline 21 & 725 & 668 & 663 & 108 & 109 & 280 & 250 \\
\hline 22 & 600 & 600 & 600 & 103 & 102 & 280 & 250 \\
\hline 23 & 432 & 560 & 572 & 98 & 97 & 408 & 390 \\
\hline 24 & 615 & 549 & 560 & 94 & 95 & 342 & 335 \\
\hline
\end{tabular}

Total cost - (Calculated by using costs in Table 1))

Model application: $\quad$ R9 817794

Direct application: $\quad$ R9 818227

Table 3 Aggregate production plan using the sectioning search and goal programming models of Goodman

\begin{tabular}{|c|c|c|c|c|c|c|c|}
\hline \multirow[b]{2}{*}{ Period } & \multirow[b]{2}{*}{ Demand } & \multicolumn{2}{|c|}{ Production (Units) } & \multicolumn{2}{|c|}{ Work-force (Men) } & \multicolumn{2}{|c|}{ Inventory (Units } \\
\hline & & Sectioning search & Goal programming & Sectioning search & Goal programming & Sectioning search & Goal programming \\
\hline 1 & 430 & 431 & 450 & 75 & 75 & 301 & 320 \\
\hline 2 & 447 & 440 & 447 & 72 & 74 & 294 & 320 \\
\hline 3 & 440 & 426 & 403 & 69 & 67 & 280 & 283 \\
\hline 4 & 316 & 392 & 375 & 65 & 63 & 356 & 342 \\
\hline 5 & 397 & 374 & 375 & 62 & 63 & 333 & 320 \\
\hline 6 & 375 & 348 & 375 & 59 & 63 & 306 & 320 \\
\hline 7 & 292 & 348 & 375 & 60 & 63 & 362 & 403 \\
\hline 8 & 458 & 386 & 375 & 63 & 63 & 290 & 320 \\
\hline 9 & 400 & 391 & 375 & 64 & 63 & 281 & 295 \\
\hline 10 & 350 & 355 & 353 & 61 & 59 & 286 & 298 \\
\hline 11 & 284 & 356 & 353 & 63 & 59 & 358 & 367 \\
\hline 12 & 400 & 399 & 353 & 68 & 59 & 357 & 320 \\
\hline 13 & 483 & 444 & 483 & 73 & 30 & 318 & 320 \\
\hline 14 & 509 & 481 & 496 & 78 & 83 & 290 & 307 \\
\hline 15 & 500 & 488 & 496 & 83 & 83 & 278 & 303 \\
\hline 16 & 475 & 508 & 496 & 88 & 83 & 311 & 324 \\
\hline 17 & 500 & 552 & 496 & 94 & 83 & 363 & 320 \\
\hline 18 & 600 & 607 & 600 & 101 & 100 & 370 & 320 \\
\hline 19 & 700 & 662 & 700 & 107 & 117 & 332 & 320 \\
\hline 20 & 700 & 699 & 700 & 112 & 117 & 331 & 320 \\
\hline 21 & 725 & 659 & 700 & 107 & 117 & 265 & 295 \\
\hline 22 & 600 & 600 & 557 & 101 & 93 & 265 & 252 \\
\hline 23 & 432 & 545 & 557 & 95 & 93 & 378 & 377 \\
\hline 24 & 615 & 553 & 557 & 93 & 93 & 316 & 319 \\
\hline
\end{tabular}

Total cost - (Calculated by using costs in Table 1)

Sectioning search: R10 625200

Goal programming: R12 237846 
Table 4 A comparison of the cost areas and total cost associated with each solution methodology (All costs calculated using Table 1)

\begin{tabular}{|c|c|c|c|c|c|c|}
\hline \multirow{3}{*}{ Costs } & \multirow{3}{*}{$\begin{array}{c}\text { Sectioning search } \\
\text { (last } 13 \text { periods) } \\
\text { R }\end{array}$} & \multirow{3}{*}{$\begin{array}{c}\text { Goal programming } \\
\text { (last } 13 \text { periods) } \\
\text { R }\end{array}$} & \multicolumn{2}{|c|}{$\begin{array}{l}\text { Separable programming: } \\
\text { Application of model costs }\end{array}$} & \multicolumn{2}{|c|}{$\begin{array}{l}\text { Separable programming: } \\
\text { Direct cost application }\end{array}$} \\
\hline & & & (last 13 periods) & (24 periods) & (last 13 periods) & (24 periods) \\
\hline & & & $\mathbf{R}$ & $\mathbf{R}$ & $\mathbf{R}$ & $\mathbf{R}$ \\
\hline Regular work-force & $408000(100)^{\mathrm{a}}$ & $408340(100)$ & $412080(101)$ & 653480 & $408000(100)$ & 649740 \\
\hline $\begin{array}{l}\text { Change in production } \\
\text { rate }\end{array}$ & $3856718(100)$ & $6783299(176)$ & 3724148 ( 97) & 4074351 & 3838973 ( 99) & 3954773 \\
\hline $\begin{array}{l}\text { Changes in work- } \\
\text { force }\end{array}$ & $602981(100)$ & $1859610(308)$ & $578620(96)$ & 635312 & $749782(124)$ & 765339 \\
\hline $\begin{array}{l}\text { Overtime and } \\
\text { idletime }\end{array}$ & $179565(100)$ & $46(0)$ & $270616(151)$ & 320716 & $44941(25)$ & 53406 \\
\hline $\begin{array}{l}\text { Inventory and } \\
\text { shortages }\end{array}$ & $3015479(100)$ & $1376231(46)$ & $2733031(91)$ & 4133935 & $2744128(91)$ & 4394969 \\
\hline Total cost & $8062743(100)$ & $10427520(129)$ & 7718495 ( 96) & 9817794 & 7785824 ( 97) & 9818227 \\
\hline
\end{tabular}

aNumbers in brackets are percentages.

regarded as the better model - the fit to the Goodman model was done for control purposes.

\section{Results and comparison}

In order to compare the results of the two SEP models with that of the two approaches, goal programming and sectioning search used by Goodman, a twenty-fourperiod planning horizon was used. The production plans for both SEP models are given in Table 2 and can, for all practical purposes, be regarded as similar. The total cost difference is negligible. The comparison between the sectioning search model and the goal programming model for this planning period is given in Table 3 . These results illustrated clearly that the cost structure used is very sensitive, so that small deviations from the global optimum plan involves large changes in the total cost. Costs are calculated for each of the production plans from the cost data in Table 1 using interpolation where necessary.

A comparison was made between the results of the four models mentioned above, on the basis of costs in the various cost areas. The starting conditions used by Goodman were unknown and therefore only the last 13 periods are compared to eliminate its effect. The comparison is given in Table 4. SEP (model application) offered an improvement of more than $4 \%$ in the total cost in comparison with the sectioning search model and performs $26 \%$ better than the GP models. These improvements are somewhat lower in the case of the SEP (direct application) $-3,4 \%$ and $25 \%$ respectively. A percentage-wise comparison is also made between the models in Table 4. The sectioning search results are used as a basis for this comparison. Major differences can be summarised as indicated in Table 5.

\section{Conclusion}

In conclusion the following advantages of the SEP approach must be underlined. This is a mathematical programming technique that can be used in a very flexible way. More linear segments may be added in cases where
Table 5 A comparison between the various models, using sectioning search results as a basis

\begin{tabular}{|c|c|}
\hline Model & $\begin{array}{l}\text { Major differences compared to the sectioning } \\
\text { search results }\end{array}$ \\
\hline $\begin{array}{l}\text { Goal } \\
\text { programming }\end{array}$ & $\begin{array}{l}\text { Changes in the work-force is dominant (approximate- } \\
\text { ly three times more), no overtime/undertime and less } \\
\text { inventory. Higher total cost. }\end{array}$ \\
\hline $\begin{array}{l}\text { SEP (model } \\
\text { application) }\end{array}$ & $\begin{array}{l}\text { More overtime/undertime and less inventory. } \\
\text { Total cost less. }\end{array}$ \\
\hline $\begin{array}{l}\text { SEP (direct } \\
\text { application) }\end{array}$ & $\begin{array}{l}\text { More changes in the work-force, less overtime/ } \\
\text { undertime and less inventory. Total cost less. }\end{array}$ \\
\hline
\end{tabular}

more accuracy is needed. In the case of monotonous cost increases (e.g. concave cost structures), the ordinary simplex algorithm may be used to solve the problem. The linear segments can be fitted graphically to real-world cost data without deriving, by means of laborious curve fitting methods, a complex mathematical model. In many cases ordinary linear curves, while in other instances (e.g. overtime pay as a linear function of normaltime pay) linear segments, represent the real world.

\section{References}

1. HOlT, C., MODigliani, F. \& SiMON, H.A. 'A Linear Decision Rule for Production Employment Scheduling', Manage. Sci., October 1955.

2. HOLT, C., MODIGLIANI, F., SIMON, H.A. \& MUTH, J.F. 'Derivation of a Linear Decision Rule for Production and Employment', Manage. Sci., January 1956.

3. HANSSMANN, F. \& HESS, W. 'A Linear Programming Ap proach to Production and Employment Scheduling', Manage. Technol., January 1960, 1(1).

4. GOODMAN, D.A. 'A New Approach to Scheduling Aggregate Production and Work Force', AIIE Transactions, June 1973,
Vol. 5.

5. GOODMAN, D.A. 'A Goal Programming Approach to Aggregate Planning of Production and Work Force', Manage. Sci., August 1974, 20(12), p.1569. 